\title{
Literasi Tatakelola BUMDES (Badan Usaha Milik Desa)
}

\author{
M. Ardiansyah Syam ${ }^{1}$, Suratno ${ }^{2}$, Syahril Djaddang ${ }^{3}$ \\ 1, 2, 3 Sekolah Pascasarjana Universitas Pancasila, Jakarta, Indonesia \\ *E-mail:m.ardiansyahsyam@univpancasila.ac.id
}

\begin{abstract}
Abstrak
Badan Usaha Milik Desa adalah lembaga usaha desa yang dikelola oleh masyarakat dan pemerintah desa dalam upaya memperkuat perekonomian desa dan membangun kemasyarakatan masyarakat yang dibentuk berdasarkan kebutuhan masyarakat desa. Sebagai badan usaha milik umum (milik desa), tata kelola dan akuntabilitas publikjuga melekat pada BUMDes. Literasi tata kelola BUMDes tidak hanya bermanfaat bagi pengelola atau pengawas BUMDes, tetapi juga bermanfaat bagi masyarakat desa terkait penggunaan aset desa yang dipisahkan untuk memenuhi kebutuhan masyarakat desa dan memberikan layanan berkualitas kepada masyarakat desa. Melalui tata kelola yang baik, BUMDes diharapkan dapat dikelola secara profesional, mandiri, dan memiliki jaringan yang baik dengan berbagai pihak sehingga dapat terkonsolidasi dan menjadikekuatan ekonomi pedesaan menuju desa yang mandiri dan mandiri.
\end{abstract}

Kata Kunci: audit sektor publik, akuntansi \& tata kelola desa, transparansi dan akuntabilitas.

\begin{abstract}
Village-owned enterprises are village business institutions that are managed by the community and village government in an effort to strengthen the village economy and build social communities that are formed based on the needs of the village community. As a publicly owned (village-owned) enterprise, public governance and accountability are also inherent in BUMDes. BUMDes governance literacy is not only beneficial for BUMDes managers or supervisors, but also benefits village communities related to the use of separated village assets to meet the needs of villa ge communities and provide quality services to village communities. Through good governance, BUMDes are expected to be managed professionally, independently, and have good networks with various parties so that they can be consolidated and become a rural economic power towards an independent and autonomous village.
\end{abstract}

Keywords: village owned enterprises, governance, community empowerment, literacy. 


\section{PENDAHULUAN}

Badan Usaha Milik Desa (BUMDes) adalah lembaga usaha desa yang dikelola oleh masyarakat dan pemerintahan desa dalam upaya memperkuat perekonomian desa dan membangun sosial masyarakat yang dibentuk berdasarkan kebutuhan desa, sebagaimana diatur dalam peraturan perundang-undangan (Undang Undang No 32 Tahun 2004 Pasal 213 ayat 2). BUMDes merupakan lembaga ekonomi desa harus berperan mulai dari hulu (upstream) sampai kesektor hilir (downstream) dari aktivitas pengembangan usaha perkebunan dan aktivitas ekonomi produktif lain yang dilakukan oleh masyarakat sesuai dengan potensi lokal desa.

BUMDes merupakan satu bentuk partisipasi masyarakat secara keseluruhan yang didirikan berdasarkan Peraturan Desa yang mengatur Pendirian BUMDes. BUMDes didirikan atas pertimbangan penyaluran inisiatif masyarakat desa, pengembangan potensi desa, pengelolaan, pemanfaatan potensi desa, pembiayaan dan kekayaan pemerintah desa yang diserahkan untuk dikelola oleh BUMDes. BUMDes memiliki tujuan yang jelas yaitu menyediakan layanan kebutuhan bagi usaha produktif diu tamakan untuk masyarakat desa yang tergolong kelompok miskin, mengurangi adanya praktek rentenir dan pelepasan uang. Pemberdayaan BUMDes tidak berbeda jauh dengan konsep-konsep pemberdayaan masyarakat yang banyak dikenal, misalnya sebagai upaya memperkuat unsur-unsur keberdayaan untuk meningkatkan harkat dan martabat lapisan masyarakat yang berada dalam kondisi yang rentan dan tidak mampu mengandalkan kekuatannya sendiri untuk keluar dari perangkap kemiskinan dan keterbelakangan, atau dengan kata lain pembe rdayaan adalah proses memampukan dan memandirikan masyarakat.

Sebagai badan usaha milik publik (milik desa), tatakelola dan akuntabilitas publik juga melekat pada BUMDes. Literasi tatakelola BUMDes tidak hanya bermanfaat bagi pengelola atau pengawas BUMDes, akan tetapi juga bermanfaat bagi masy arakat desa terkait dengan penggunaan kekayaan atau aset desa yang dipisahkan untuk memenuhi kebutuhan dan memberikan pelayanan yang berkualitas bagi masyarakt desa. Melalui tatakelola yang baik (good governance), BUMDes diharapkan dikelola secara professional, mandiri, dan memiliki jejaring kerja yang baik dengan berbagai pihak sehingga mampu dikonsolidasikan dan menjadi kekuatan ekonomi perdesaan menuju desa mandiri dan otonom.

\section{TINJAUAN PUSTAKA}

\section{Pengertian Desa dan BUMDES}

Desa adalah desa dan desa adat atau yang disebut dengan nama lain, selanjutnya disebut Desa, adalah kesatuan masyarakat hukum yang memiliki batas wilayah yang 
berwenang untuk mengatur dan mengurus urusan pemerintahan, kepentingan masyarakat setempat berdasarkan prakarsa masyarakat, hak asal usul, dan/atau hak tradisional yang diakui dan dihormati dalam sistem pemerintahan Negara Kesatuan Republik Indonesia.

Badan Usaha Milik Desa, selanjutnya disebut BUM Desa, adalah badan usaha yang seluruh atau sebagian besar modalnya dimiliki oleh desa melalui penyertaan secara langsung yang berasal dari kekayaan desa yang dipisahkan guna mengelola aset, jasa pelayanan, dan usaha lainnya untuk sebesar-besarnya kesejahteraan masyarakat desa.

\section{Landasan Hukum BUMDES}

Disahkannya UU Nomor 6 Tahun 2014 tentang Desa, memberikan konsekuensi bahwa desa diberikan kesempatan yang besar untuk mengurus tata pemerintahannya sendiri serta pelaksanaan pembangunan untuk meningkatkan kesejahteraan dan kualitas hidup masyarakat desa. Selain itu pemerintah desa diharapkan untuk lebih mandiri dalam mengelola pemerintahan dan berbagai sumber daya alam yang dimiliki, termasuk di dalamnya pengelolaan keuangan dan kekayaan milik desa. Begitu besar peran yang diterima oleh desa, tentunya disertai dengan tanggung jawab yang besar pula. Oleh karena itu pemerintah desa harus bisa menerapkan prinsip akuntabilitas dalam tata pemerintahannya, dimana semua akhir kegiatan penyelenggaraan pemerintahan desa harus dapat dipertanggungjawabkan kepada masyarakat desa sesuai dengan ketentuan.

Peraturan pelaksanaan dari UU Nomor 6 Tahun 2014 yang telah ada sampai dengan saat ini yaitu PP Nomor 43 Tahun 2014 tentang Desa, PP Nomor 60 Tahun 2014 tentang Dana Desa yang Bersumber dari APBN, serta beberapa aturan teknis dari Kementrian Dalam Negeri diantaranya yaitu Permendagri Nomor 113 Tahun 2014 tentang Pengelolaan Keuangan Desa. Pengelolaan Keuangan Desa untuk terakhir kalinya diubah dalam Peraturan Menteri Dalam Negeri Nomor 20 Tahun 2018 tentang Pengelolaan Keuangan Desa pada tanggal 11 April 2018 dan mulai berlaku sejak tanggal diundangkannya Permendagri Nomor 20 Tahun 2018.

Secara ringkas, landasan hukum pendirian Badan Usaha Milik Desa dapat dijelaskan sebagai berikut:

1. UU No. 32 Tahun 2004 Psal 213:

a) Desa dapat mendirikan badan usaha milik desa sesuai dengan kebutuhan dan potensi desa.

b) Badan usaha milik desa sebagaimana dimaksud pada ayat (1) perpedoman pada peraturan perundang-undangan. 
c) Badan usaha milik desa sebagaimana dimaksud pada ayat (1) dapat melakukan pinjaman sesuai perundang-undangan.

2. UU No. 6 tahun 2014 tentang Desa

a) Desa dapat mendirikan badan usaha milik desa yang disebut BUMDes.

b) BUMDes dikelelola dengan semangat kekeluargaan dan kegotong royongan.

c) BUMDes dapat menjalankan usaha di bidang ekonomi atau pelayanan umum sesuai dengan ketentuan peraturan perundang-undangan.

3. Peraturan Pemerintah Nomor 47 Tahun 2015 tentang Perubahan Atas Peraturan Pemerintah Nomor 43 Tahun 2014 tentang Peraturan Pelaksanaan Undang-Undang Nomor 6 Tahun 2014 tentang Desa

4. Peraturan Menteri Desa, Pembangunan Daerah Tertinggal dan Transmingrasi No. 4 Tahun 2015 tentang Pendirian, Pengurusan dan Pengelolaan, dan Pembubaran Badan Usaha Milik Desa

Secara grafis, landasan hukumpendirian Badan Usaha Milik Desa dapat dilihat pada gambar 1.

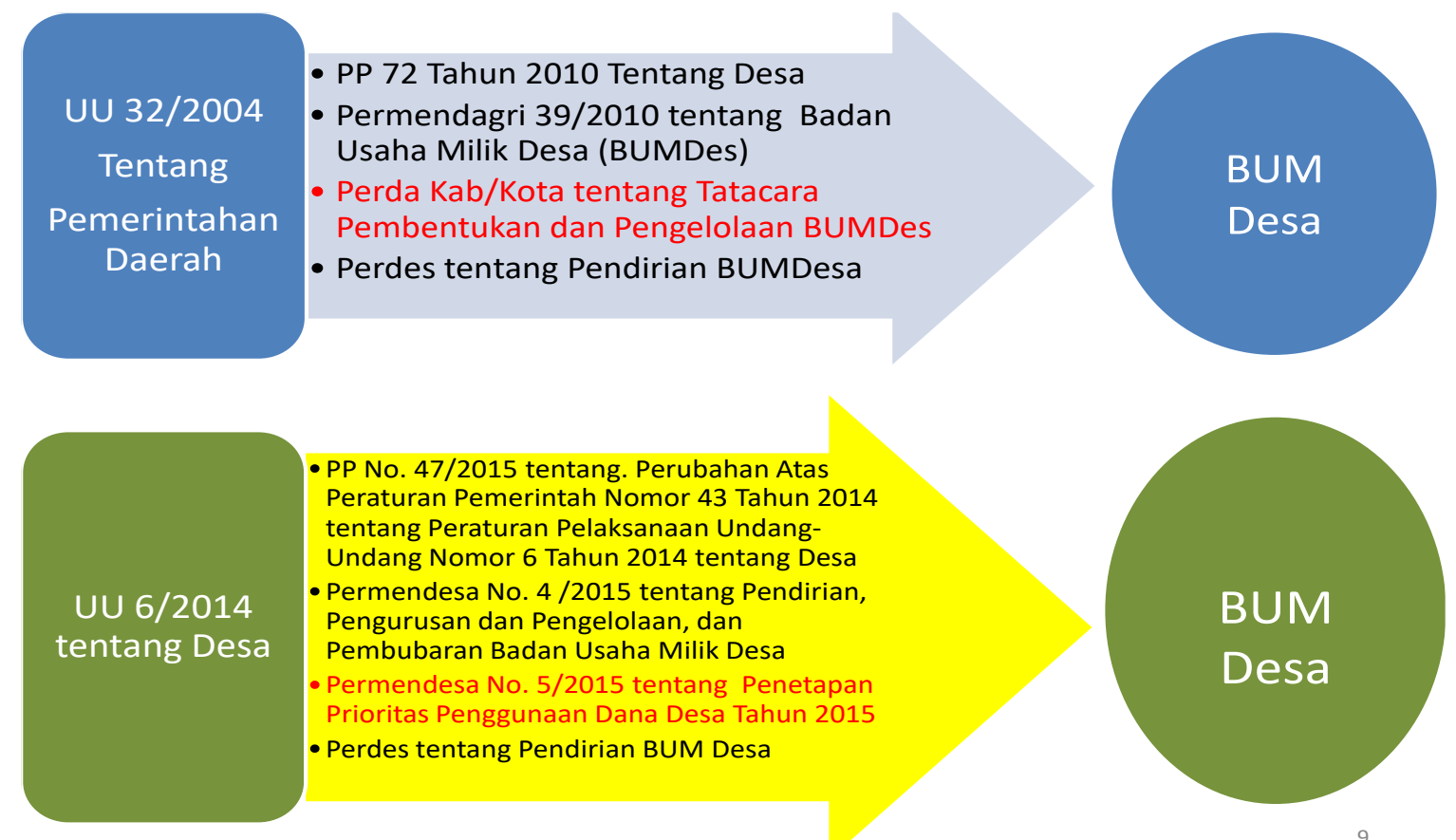

Sumber: Diadaptasi dari berbagai sumber dan Permendesa PDTT No 4 Tahun 2015

Gambar 1:

Landasan Hukum Pendirian Badan Usaha Milik Desa 


\section{Pendirian BUMDES}

Pendirian BUM Desa dimaksudkan sebagai upaya menampung seluruh kegiatan di bidang ekonomi dan/atau pelayanan umum yang dikelola oleh Desa. Tujuan pembentukan Badan Usaha Milik Desa (BUMDes) dimaksudkan untuk mendorong atau menampung seluruh kegiatan peningkatan pendapatan masyarakat, baik yang berkembang menurut adat istiadat dan budaya setempat, maupun kegiatan perekonomian yang diserahkan untuk di kelola oleh masyarakat melalui program atau proyek pemerintah pusat dan pemerintah daerah. Sebagai sebuah usaha desa, pembentukan BUMDes adalah untuk memaksimalisasi potensi masyarakat desa baik itu potensi ekonomi, sumber daya alam, ataupun sumber daya manusianya. Secara spesifik, pendirian BUMDes adalah untuk menyerap tenaga kerja desa meningkatkan kreatifitas dan peluang usaha ekonomi produktif mereka yang berpenghasilan rendah. Sasaran pemberdayaan ekonomi masyarakat desa melalui BUMDes ini adalah untuk melayani masyarakat desa dalam mengembangkan usaha produktif. Adapun tujuan yang ingin dicapai dengan pendirian BUMDes dalam konteks pembangunan desa yaitu:

1. meningkatkan perekonomian desa;

2. mengoptimalkan aset desa agar bermanfaat untuk kesejahteraan desa;

3. meningkatkan usaha masyarakat dalam pengelolaan potensi ekonomi desa;

4. mengembangkan rencana kerja sama usaha antar desa dan/atau pihak ketiga;

5. menciptakan peluang dan jaringan pasar yang mendukung kebutuhan layanan umum warga;

6. membuka lapangan kerja;

7. meningkatkan kesejahteraan masyarakat melalui perbaikan pelayanan umum, pertumbuhan dan pemerataan ekonomi desa; dan

8. meningkatkan pendapatan masyarakat desa dan pendapatan asli desa.

Pendirian BUM Desa disepakati melalui Musyawarah Desa, sebagaimana diatur dalam Peraturan Menteri Desa, Pembangunan Daerah Tertingggal, dan Transmigrasi tentang Pedoman Tata Tertib dan Mekanisme Pengambilan Keputusan Musyawarah Desa. Pokok bahasan yang dibicarakan dalam Musyawarah Desa meliputi :

a. Pendirian BUM Desa sesuai dengan kondisi ekonomi dan sosial budaya masyarakat;

b. Organisasi pengelola BUM Desa;

c. Modal usaha BUM Desa; dan 
d. Anggaran Dasar dan Anggaran Rumah Tangga BUM Desa. Hasil kesepakatan Musyawarah Desa menjadi pedoman bagi Pemerintah Desa dan Badan Permusyawaratan Desa untuk menetapkan Peraturan Desa tentang Pendirian BUMDesa.

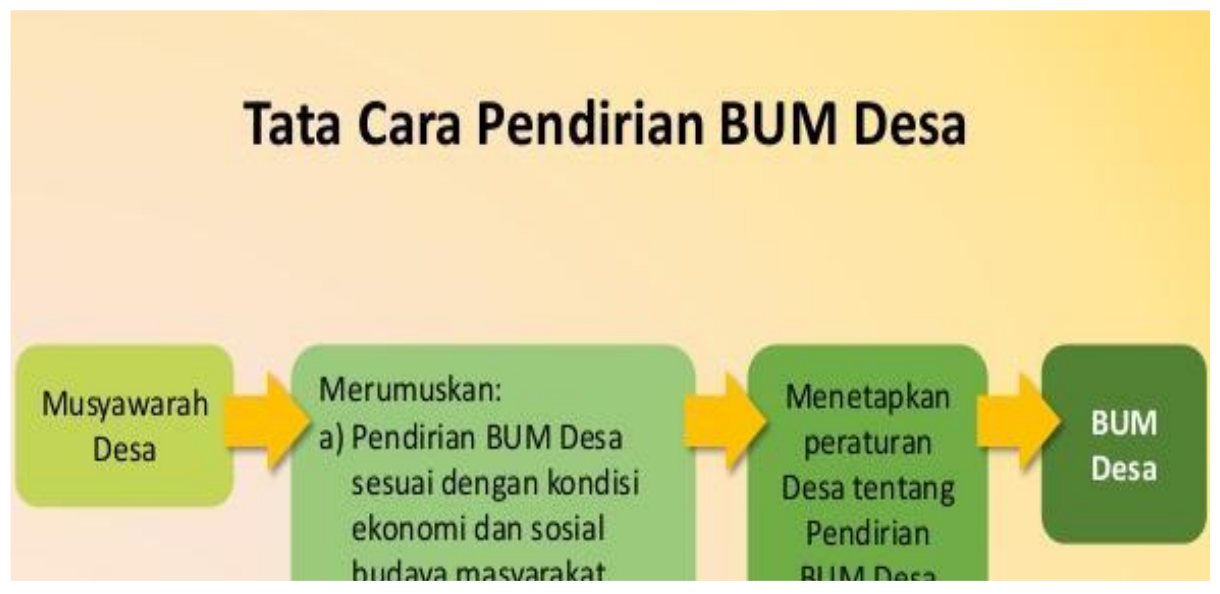

Sumber: Diadaptasi dari Permendesa PDTT No 4 Tahun 2015

Gambar 2:

Pendirian Badan Usaha Milik Desa

Dalam rangka kerja sama antar-Desa dan pelayanan usaha antar-Desa dapat dibentuk BUM Desa bersama yang merupakan milik 2 (dua) Desa atau lebih. Pendirian BUM Desa bersama sebagaimana dimaksud pada ayat (1) disepakati melalui Musyawarah antar-Desa yang difasilitasi oleh badan kerja sama antar-Desa yang terdiri dari: a. Pemerintah Desa; b. anggota Badan Permusyawaratan Desa; c. lembaga kemasy arakatan Desa; d. lembaga Desa lainnya; dan e. tokoh masyarakat dengan mempertimbangkan keadilan gender. Ketentuan mengenai Musyawarah Desa sebagaimana dimaksud dalam Pasal 5 berlaku secara mutatis mutandis terhadap pendirian BUM Desa bersama. BUM Desa bersama ditetapkan dalam Peraturan Bersama Kepala Desa tentang Pendirian BUM Desa bersama.

\section{Tatakelola dan Akuntabilitas Publik}

Tatakelola BUMDes juga tunduk pada Tatakelola Keuangan Desa yang dikelola berdasarkan praktik-praktik pemerintahan yang baik. Asas-asas Pengelolaan Keuangan Desa sebagaimana tertuang dalam Permendagri Nomor 113 Tahun 2014 yaitu transparan, akuntabel, partisipatif serta dilakukan dengan tertib dan disiplin anggaran, dengan uraian sebagai berikut: 
1. Transparan yaitu prinsip keterbukaan yang memungkinkan masyarakat untuk mengetahui dan mendapat akses informasi seluas-luasnya tentang keuangan desa. Asas yang membuka diri terhadap hak masyarakat untuk memperoleh informasi yang benar, jujur, dan tidak diskriminatif tentang penyelenggaraan pemerintahan desa dengan tetap memperhatikan ketentuan peraturan perundang-undangan;

2. Akuntabel yaitu perwujudan kewajiban untuk mempertanggungjawabkan pengelolaan dan pengendalian sumber daya dan pelaksanaan kebijakan yang dipercayakan dalam rangka pencapaian tujuan yang telah ditetapkan. Asas akuntabel yang menentukan bahwa setiap kegiatan dan hasil akhir kegiatan penyelenggaraan pemerintahan desa harus dapat dipertanggungjawabkan kepada masyarakat desa sesuai dengan ketentuan peraturan perundang- undangan;

3. Partisipatif yaitu penyelenggaraan pemerintahan desa yang mengikutsertakan kelembagaan desa dan unsur masyarakat desa;

4. Tertib dan Disiplin Anggaran yaitu pengelolaan keuangan desa harus mengacu pada aturan atau pedoman yang melandasinya.

Sebagai badan usaha milik publik (milik desa) pengelolaan BUMDes juga tunduk pada beberapa ketentuan terkait dengan pertanggungjawaban publik (akuntabilitas publik). Dalam organisasi sektor publik, pertanggungjawaban publik atau lebih dikenal dengan akuntabilitas publik merupakan pertanggungjawaban atas tindakan dan keputusan dari para pemimpin/pengelola organisasi sektor publik kepada pihak yang memiliki kepentingan (stakeholder) serta masyarakat. Akuntabilitas merupakan konsep etika yang dekat dengan administrasi publik pemerintahan (lembaga eksekutif pemerintah, lembaga legislatif parlemen dan lembaga yudikatif) yang memunyai beberapa arti antara lain, hal ini sering digunakan secara sinonim dengan konsep-konsep seperti yang dapat dipertanggungjawabkan (responbility), yang dapat dipertanyakan (answerbility), yang dapat dipersalahkan (blameworthiness) dan yang memunyai keterkaitan dengan harapan dapat menerangkan salah satu aspek dari administrasi publik/pemerintah.

Transparansi dan akuntabilitas adalah dua kata kunci dalam penyelenggaraan pemerintahan maupun penyelenggaraan perusahaan yang baik, dinyatakan juga bahwa dalam akuntabilitas terkandung kewajiban untuk menyajikan dan melaporkan segala kegiatan terutama dalam bidang administrasi keuangan kepada pihak yang lebih tinggi. Akuntabilitas dapat dilaksanakan dengan memberikan akses kepada semua pihak yang berkepentingan, bertanya atau menggugat pertanggungjawaban para pengambil keputusan dan pelaksana baik ditingkat program, daerah dan masyarakat. 
Berdasarkan definisi di atas, maka dapat ditarik kesimpulan bahwa akuntabilitas merupakan suatu perwujudan kewajiban seseorang atau kelompok dalam suatu unit organisasi untuk memertanggungjawabkan setiap kegiatan dalam hal pengelolaan dan pengendalian sumber daya dan pelaksana kebijakan yang dimandatkan kepadanya dalam rangka untuk mencapai tujuan yang telah ditetapkan.

\section{METODE}

Salah satu upaya untuk meningkatkan literasi tatakelola BUMDes adalah melalui penyelenggaraan seminar publik dengan kelompok sasaran pengelola BUMDes, para pendamping desa dan masyarakat secara umum.

Fase 1: Pengenalan, fase pengenalan ini bertujuan untuk memetakan tingkat literasi keuangan \& tatakelola dan meningkatkan pemahaman tentang literasi keuangan \& tatakelola pengurus BUMDes dan seluruh stakeholders.

Fase 2: Pengembangan, dalam fase ini dilakukan pengembangan indikator-indikator tatakelola yang paling sesuai dengan karakteristik BUMDes dengan 6 dimensi yaitu (1) kooperatif, (2) partisipatif, (3) emansipatif, (4) transparan, (5) akuntabel dan (6) sustainabel. Fase 3: Pemberdayaan, fase ini pemberdayaan mahasiswa, tenaga pendamping desa dan unsur masyarakat lainnya untuk memberikan literasi tatakelola BUMDes secara lebih luas.

Fase 2: Pengembangan

Fase 3: Pemberdayaan

Fase 1: Pengenalan

Gambar 3: Literasi Tatakelola, Pengembangan Indikator dan Pemberdayaan BUMDes 
Melalui 3 fase pelaksanaan pengabdian masyarakat ini, diharapkan akan memberikan dampak positif bagi upaya menciptakan Tatakelola BUMDes secara terintegrasi dan berdampak secara luas.

\section{PEMBAHASAN}

BUMDes memiliki peran yang penting bagi perekonomian pemerintahan desa untuk meningkatkan kesejahteraan warganya. Apabila dikelola dengan baik maka akan memberikan dampak yang besar bagi pertumbuhan ekonomi desa. Dengan demikian akan mendorong lahirnya desa desa mandiri dengan pengelolaan yang lebih akuntabel dan transparan. Peran masyarakat desa yang partisipatif dan semangat gotong royong juga berhasil mendukung BUMDes dalam meningkatkan ekonomi pemerintahan desa.

Sebagai enititas bisnis yang dimiliki oleh public, tata kelola BUMDes juga tunduk pada beberapa prinsip tatakelola yang baik (good corporate governance) dan tata pemerintahan yang baik (goodgovernment governance). Prinsip-prinsip tatakeloa BUMDes, antara lain:

1. Kooperatif, adanya partisipasi keseluruhan komponen dalam pengelolaan BUMDes dan mampu saling bekerja sama dengan baik

2. Partisipatif, keseluruhan komponen yang ikut terlibat dalam pengelolaan BUMDes diharuskan memberikan dukungan serta kontribusi secara sukarela atau tanpa diminta untuk meningkatkan usaha BUMDes

3. Emansipatif, keseluruhan komponen yang ikut serta dalam pengelolaan BUMDes diperlakukan seimbang tanpa membedakan golongan, suku, dan agama

4. Transparan, seluruh kegiatan yang dilaksanakan dalam pengelolaan BUMDes dan memiliki pengaruh pada kepentingan umum harus terbuka dan segala lapisan masyarakat mengetahui seluruh kegiatan tersebut

5. Akuntabel, keseluruhan kegiatan secara teknis maupun administrative harus dipertanggung jawabkan

6. Sustainabel, masyarakat mengembangkan dan melestarikan kegiatan usaha dalam BUMDes.

Melalui BUMDes upaya pemerintah desa dalam rangka menanggulangi kemiskinan dengan memajukan ekonomi desa dapat dikelola dengan profesional dan dapat dipertanggungjawabkan. Kebutuhan masyarakat dan potensi desa dapat dipertemukan dalam unit-unit usaha yang diselenggarakan oleh BUMDes. Orientasi BUMDes tidak selalu pada keuntungan, namun dengan adanya BUMDes diharapkan dapat menumbuhkan kembali nilai-nilai sosial lokal dan kepedulian sosial terhadap masyarakat yang kurang beruntung. 
Untuk mewujudkan BUMDes yang sukses, maka dibutuhkan strategi perencanaan dan pijakan yang kuat. Terutama bagi desa yang baru membangun BUMDes.

Beberapa peneliti terdahulu meneliti mengenai akuntanbilitas publik. Fitriana, Utami, dan Hapsari (2018) meneliti akuntabilitas pengelolaan dana BUMDes BersamaKecamatan Susukan Kabupaten Semarang. Hasil penelitian menunjukkan bahwa terdapat ketidaksesuaian antara laporan dengan pelaksanaan akivitas, pencairan dana yang tidak didukung bukti, dan verifikasi laporan tidak dilakukan setiap bulan, yang mengindikasi bahwa akuntabilitas masih relatif belum berjalan dengan baik. Pramita (2018) dalam penelitiannya menemukan bahwa pemahaman pengurus BUMDes mengenai Peraturan Menteri Desa, Pembangunan Daerah Tertinggal, dan Transmigrasi Republik Indonesia No 4 Tahun 2015 tentang Pendirian, Pengurusan dan Pengelolaan, dan pembubaran Badan Usaha Milik Desa dan pemanfaatan sistem informasi berpengaruh positif pada akuntabilitas pengelolaan BUMDes di Kabupaten Magelang. Riset tersebut dapat menyimpulkan bahwa salah satu faktor yang menyebabkan perkembangan BUMDes kurang optimal adalah masalah tata kelola (Corporate Governance/CG) BUMDes. Widiastuti et al (2019) memberi kontribusi bagi para pegiat BUMDes untuk memberikan pendampingan yang tepat setelah menakar tata kelola y ang dimiliki oleh BUMDes. Secara teoritis, riset ini memberi tambahan konsep pada teori social enterprise dalam konteks BUMDes yang merupakan

\section{SIMPULAN DAN SARAN}

Dalam beberapa penelitian sebelumnya, diperoleh kesimpulan bahwa secara umum, tingkat keterterapan tata kelola BUMDes di Indonesia masih relatif rendah (Fitriana, Utami dan Hapsari, 2018; Pramitha, 2018; Widiastuti, 2019). Tingkat keterterapan tata kelola BUMDes nampak berkorelasi dengan umur BUMDes, untuk itu meningkatkan literasi tatakelola BUMDes. Julian dan Muslimin (2019), menemukan bahwa sumber daya manusia pengelola BUMDes sebagian besar tidak memiliki pengetahuan dan kecakapan untuk menjalankan tatakelola BUMDes secara baik dan benar.

Sebagaimana disarankan oleh Widiastuti et al (2019), perlu untuk menentukan rancangan indikator- indikator yang dapat digunakan untuk menilai dan men gevaluasi tata kelola BUMDes. Indikator- indikator disusun berdasakan kajian regulasi dan literatur, serta FGD dengan pengelola BUMDes yang kemudian diklasifikasi sesuai konsep enam prinsip tata kelola BUMDes, yaitu (1) kooperatif, (2) partisipatif, (3) emansipatif, (4) transparan, (5) akuntabel dan (6) sustainabel.

Berdasarkan hasil dan temuan beberapa penelitian sebelumnya, direkomendasikan beberapa hal dapat ditindaklanjuti: 
1. Meningkatkan literasi tatakelola BUMDes, tidak saja bagi pengurus, akan tetapi kepada masyarakat dan seluruh pemangkukepentingan (stakeholders) BUMDes.

2. Langkah selanjutnya adalah perlunya mengembangkan dan merancang indikatorindikator tatakelola BUMDes berdasarkan prinsip tata kelola yang baik (good corporate governance dan good government governance).

3. Penetapan Standardisasi Tata Kelola Pengelolaan BUMDes melalui Sekretariat Bersama (Kemendagri, Kemenkeu dan Kementerian Desa, Daerah Tertinggal dan Transmigrasi) dan Perlunya Perumusan dan Penetapan Standar Akuntansi Keuangan Desa, BUMDes dan Integrasi Aplikasi Keuangan Desa dengan Aplikasi BUMDes berbasis Komputer.

4. Perlunya pembinaan dan peningkatan kapasitas aparatur desa dan pendamping desa dalam pengelolaan dana desa, khususnya terkait dengan pengelolaan BUMDes.

5. Perlunya memberikan pembekalan kompetensi yang cukup untuk mengawal dana desa yang dialokasikan untuk mendirikan dan mengoperasikan BUMDes meliputi (Perencanaan, Pengelolaan, Penatausahaan, Pelaporan dan Pertanggungjawaban).

\section{REFERENSI}

Arens, Alvin A, Randall J. Elder, Mark S. Beasley, \& Chris E. Hogan (2016). Auditing and Assurance Services: An Integrated Approach, $17^{\text {th }}$ Edition, Pearson, Boston USA.

Badan Pengawasan Keuangan dan Pembangunan (BPKP),. (2015): Petunjuk Pelaksanaan Bimbingan \& Konsultasi Pengelolaan Keuangan Desa, Deputi Bidang Pengawasan Penyelenggaraan Keuangan Daerah, BPKP Pusat, Jakarta.

Bastian, Indra (2014). Audit Sektor Publik: Pemeriksaan Pertanggungjawaban Pemerintahan, Edisi 3. Salemba Empat. Jakarta

Fitriana, R. L., Utami, I., \& Hapsari, A. N. S. (2018). Pengelolaan dana: Sisi akuntabilitas Badan Usaha Milik Desa. Prosiding Konferensi Regional Akuntansi V (pp. 1-29)

Hafidh, R. A. (2017). Tata Kelola Badan Usaha Milik Desa (Studi Di Bumdes Danar Kabupaten Garut). Retrieved from http://repository.ub.ac.id/4643/

Juliman, \& Muslimin, A. (2019). Optimalisasi Tatakelola Badan Usaha Milik Desa. Jurnal Penelitian Pendidikan Sosial Humaniora, 4(1), 471-483.

Murwanto, Adi Budiarso, \& Fajar Hasri Ramadhana (2017). Audit Sektor Publik: Suatu Pengantar bagi Pembangunan dan Akuntabilitas Pemerintah, Lembaga Pengkajian 
Keuangan Publik dan Akuntansi Pemerintah. Badan Pendidikan dan Pelatihan Keuangan, Departemen Keuangan Republik Indonesia. Jakarta.

Nafis, A. G. R., \& Millaturrofi'ah, M. (2019). BumDes Pay sebagai Katalisator Ketahanan Ekonomi Desa. Proceeding of Community Development, 2(6), 865.

Pramita, Y. D. (2018). The analysis of understanding Permendesa No. 4 year 2015 and use of information systems on Bumdes management accountability. Jurnal Analisis Bisnis Ekonomi, 16(4), 1-8. Purnomo,

Widiastuti, H., Putra, W. M., Utami, E. R., \& Suryanto, R. (2019). Menakar Tata Kelola Badan Usaha Milik Desa di Indonesia. Jurnal Ekonomi Dan Bisnis, 22(2), 257-288.

Zulbetti, R., Perwito, P., \& Puspita, V. A. (2019). Upaya Peningkatan Literasi Keuangan Pengurus BUMDES Melalui Pelatihan Keuangan di Kecamatan Cimaung Kabupaten Bandung. Ekonomikawan: Jurnal Ilmu Ekonomi Dan Studi Pembangunan, 19(2), 200211.

\section{Undang-Undang dan Peraturan:}

1. Undang-Undang Republik Indonesia Nomor 32 Tahun 2004 Tentang Pemerintahan Daerah

2. Undang-undang Republik Indonesia No 6 Tahun 2014 tentang Desa.

3. Peraturan Pemerintah Nomor 43 Tahun 2014 tentang Peraturan Pelaksanaan UU Nomor 6 Tahun 2014 tentang Desa;

4. Peraturan Pemerintah Nomor 60 Tahun 2014 tentang Dana Desa yang Bersumber dari APBN;

5. Peraturan Presiden Nomor 11 Tahun 2015 tentang Kementerian Dalam Negeri;

6. Peraturan Presiden Nomor 12 Tahun 2015 tentang Kementerian Desa, iL Daerah Tertinggal dan Transmigrasi;

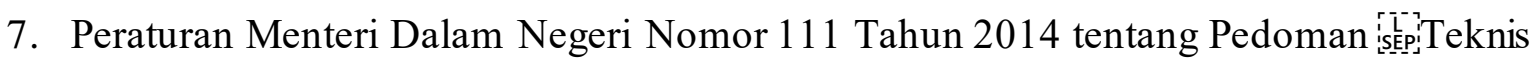
Peraturan di Desa;

8. Peraturan Menteri Dalam Negeri Nomor 113 Tahun 2014 tentang Pengelolaan Keuangan Desa;

9. Peraturan Menteri Dalam Negeri Nomor 114 Tahun 2014 tentang Pedoman Pembangunan Desa; 
10. Peraturan Menteri Dalam Negeri Nomor 114 Tahun 2014 tentang Pengelolan keuangan Desa;

11. Peraturan Menteri Dalam Negeri Republik Indonesia Nomor 20 Tahun 2018 Tentang Pengelolaan Keuangan Desa

12. Peraturan Menteri Desa, Pembangunan Daerah Tertinggal, dan Transmigrasi ictepi Nomor

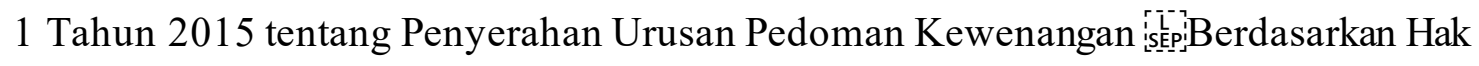
Asal Usul dan Kewenangan Lokal Berskala Desa;

13. Peraturan Menteri Desa, Pembangunan Daerah Tertinggal, dan Transmigrasi Nomor 2 Tahun 2015 tentang Pedoman Tata Tertib dan Mekanisme iscepiPengambilan Keputusan Musyawarah Desa;

14. Peraturan Menteri Desa, Pembangunan Daerah Tertinggal, dan Transmigrasi isepein Nomor 3 Tahun 2015 tentang Pendampingan Desa;

15. Peraturan Menteri Desa, Pembangunan Daerah Tertinggal, Dan Transmigrasi Republik Indonesia Nomor 4 Tahun 2015 Tentang Pendirian, Pengurusan dan Pengelolaan, dan Pembubaran Badan Usaha Milik Desa

16. Peraturan Menteri Desa, Pembangunan Daerah Tertinggal, dan Transmigrasi icepi Nomor 5 Tahun 2015 tentang Penetapan Prioritas Penggunaan Dana Desa

17. Peraturan Menteri Desa, Pembangunan Daerah Tertinggal, dan Transmigrasi isepes Nomor 11 Tahun 2019 tentang Prioritas Penggunaan Dana Desa tahun 2020.

18. Peraturan Menteri Desa, Pembangunan Daerah Tertinggal, dan Transmigrasi 6 tahun 2020 tentang Perubahan atas Permendesa PDTT Nomor 11 Tahun 2019 tentang Prioritas Penggunaan Dana Desa tahun 2020

19. Peraturan Menteri Keuangan Nomor 241/PMK.07/2014 tentang Pelaksanaan istẹpidan Pertanggungjawaban Transfer ke Daerah dan Dana Desa;

20. Peraturan Menteri Keuangan Nomor 250/PMK.07/2014 tentang Pengalokasian Transfer ke Daerah dan Dana Desa;

21. Peraturan Menteri Keuangan Nomor 263/PMK.05/2014 tentang Sistem Akuntansi dan Pelaporan Keuangan Transfer ke Daerah dan Dana Desa. 